\title{
Impedimetric Cell Detection using Microfluidic Viscoelastic Focusing
}

\section{Mikroakışkan Viskoelastik Hizalama ile Empedansa Dayalı Hücre Algılama}

\author{
Çăglar Elbüken ${ }^{1}$ iD \\ ${ }^{1}$ UNAM- National Nanotechnology Research Center and Institute of Materials Science and Nanotechnology, Bilkent University, 06800 \\ Ankara, TURKEY
}

Başvuru/Received: $25 / 02 / 2019$

Kabul/Accepted: $30 / 05 / 2019$

Son Versiyon/Final Version: 30/06/2019

\begin{abstract}
Identification and successive separation of cell populations have a vast number of applications in both clinical research and basic sciences. In the last few decades several custom-made microfluidic systems have been developed to address the differentiation needs of the researchers. For all these systems there is a need for focusing the cells of interest in the interrogation zone during the flow. In this article, a new method of viscoelastic focusing was used for this purpose. By adding polymeric materials into the carrying fluid, elastic lift force was generated on the cells that allows passive particle focusing. Once the cells are aligned with the sensor, detection and identification was achieved using impedance characterization. The carrier fluid properties were investigated to achieve successful viscoelastic focusing and impedimetric detection. Two blood cell types, red blood cells and white blood cells, were differentiated based on their impedance signal. In addition to its capability as a microfluidic cell counter, this work reveals the possibility of using viscoelastic focusing for flow through impedance based particle characterization.
\end{abstract}

\section{Key Words}

"Microfluidics, cell counting, impedance detection, viscoelastic focusing"

\section{$\ddot{O} z$}

Farklı tipteki hücrelerin karakterize edilebilmesi ve ayrıştırılması hem klinik araştırmalarda hem de temel bilimde çok fazla uygulama alanı olan konulardır. Son yıllarda araştırmacıların çalıştıları hücre tiplerine özel algılama yapabilen birçok mikroakışkan sistem geliştirilmiştir. Bütün bu sistemler için en temel gereksinim hücrelerin algılama yapılan bölgede hizalanmalarının sağlanmasıdır. Bu çalışmada hücre hizalaması ve sonrasında algılama için yeni bir teknik olan viskoelastik hizalama kullanılmıştır. Taşıyıcı sıvıda polimerik malzemeler çözülerek, sıvıdaki hücreler üzerinde bir elastik kaldırma kuvveti oluşturulmuş̧ur. Böylece hücrelerin pasif olarak algılama bölgesinde hizalanması sağlanmış ve sonrasında empedans tabanlı ölçüm ile hücre tipi algılaması gerçekleştirilmiştir. Taşıyıcı sıvının özellikleri hem viskoelastik hizalama hem de empedans algılamayı başarııı kılacak şekilde optimize edilmiştir. Deneylerde kırmızı kan hücreleri ile beyaz kan hücrelerinin empedans sinyaline göre ayrıştırılabildiği görülmüsştür. Bu çalışmada sunulan yenilikçi parçacık hizalayıcı sistem bir hücre sayma cihazı olmanın yanında, farklı tipte hücrelerin algılaması için de kullanılabilecek bir akış tipi parçacık analiz yöntemidir.

\section{Anahtar Kelimeler}

"Mikroakışkan, hücre sayımı, empedans tabanlı algılama, viskoelastik hizalama" 


\section{Introduction}

Flow through particle characterization systems can be primarily divided into two categories as optical and electrical systems (Yi et al. 2006; Holmes and Morgan 2010). For both types of systems a fundamental requirement is the alignment of the particles with the detection zone, either a focused optical signal or a concentrated electric field. Then, the interaction of the particle with this detection signal leads to sensing signal that is further processed and used for particle counting or particle characterization systems. For that purpose, the flow through particle characterization systems require a particle focusing mechanism. In the literature, the most commonly used particle focusing techniques are alignment by hydrodynamic focusing (Dziubinski 2012) and flow field fractionation (Wahlund 2013). Hydrodynamic focusing uses an auxiliary fluid to create a sheet flow of the fluid under investigation. The sample solution is squeezed by the auxiliary fluid and aligned with the sensing zone. Although this is a well-developed technique it requires multiple inlets and additional side flows which increases the instrumentation cost (Daniele et al. 2015). Flow field fractionation is a fairly straightforward technique and has no additional cost of implementation, however it requires a priori information about the particle size to be detected and is prone to clogging for clumped particles (Schauer 1995; Yamada and Seki 2006). In order to address these problems, viscoelastic focusing systems gained momentum in the last few years, where 3D particle focusing was achieved by the elastic lift force generated passively in a single fluid (Go, Byeon, and Lee 2017). Hence, viscoelastic focusing combines the precision and flexibility of hydrodynamic focusing and the simplicity of flow field fractionation. There exit excellent articles that summarize the theory of viscoelastic focusing (Romeo et al. 2013; Yuan et al. 2018; Lu et al. 2017; D'Avino, Greco, and Maffettone 2017).

In this work, viscoelastic focusing is utilized for detection of red blood cells and white blood cells using an impedimetric microfluidic detection system. The key question that is addressed is the applicability of viscoelastic focusing, hence viscoelastic fluids, for detection and differentiation of blood cells for impedimetric sensing. This has been an open question in the literature, since impedimetric detection is based on an electrical signal contrast between the particles and the particle carrying medium. Hence, for most studies the carrier medium was optimized to obtain a contrast between the medium and the particles to be detected. However, in the case of viscoelastic fluids there is limited control on the properties of the fluid. The fluid is optimized to obtain the rheological properties needed for the focusing performance. In this study, it is demonstrated that optimal solution properties can be obtained by joint effect of numerical and experimental work to simultaneously achieve viscoelastic focusing and impedimetric detection for differentiation of red blood cells and white blood cells. To the best of my knowledge, this is the first study that performs such an impedimetric differentiation using viscoelastic fluids.

\section{Materials and Methods}

In this section, the methodology and the materials used for the detection system is explained. Firstly, the details of the experimental setup is given (section 2.1) followed by the design of the microchannel and microelectrodes (section 2.2). Then, the optimization of the viscoelastic solution was given for both rheological performance (section 2.3) and cellular viability (section 2.4).

\subsection{Impedimetric Detection Setup}

The impedimetric cell detection system is composed of a high-end lock-in amplifier (Zurich Instruments, HF2LI), a transimpedance amplifier (Zurich Instruments, HF2TA), a microchannel equipped with coplanar microelectrodes and a fluid pumping system (Elveflow OB1). For the initial flow characterization experiments, a microscope (Omano inverted) equipped with a camera (Phantom Miro) was used. An image of the experimental setup is given in Figure 1. The cells are suspended in a viscoelastic fluid and pumped through the microchannel using a pressure pump. The microchannel is composed of a single inlet and a single outlet and was fabricated by conventional PDMS (polydimethyl siloxane) soft lithography. The microchannel was bonded to a glass slide which has microfabricated gold electrodes manufactured using thermal evaporation of thin metal layers and lift-off. A three electrode design was used in this study, where the middle electrode provides the AC excitation signal generated by the lock-in amplifier with its built in signal generator. The two side electrodes were used as sensing and reference electrodes. By applying a differential measurement, the system rejected the drift that may potentially originate from electrode surface property or temperature changes over the course of the measurements.

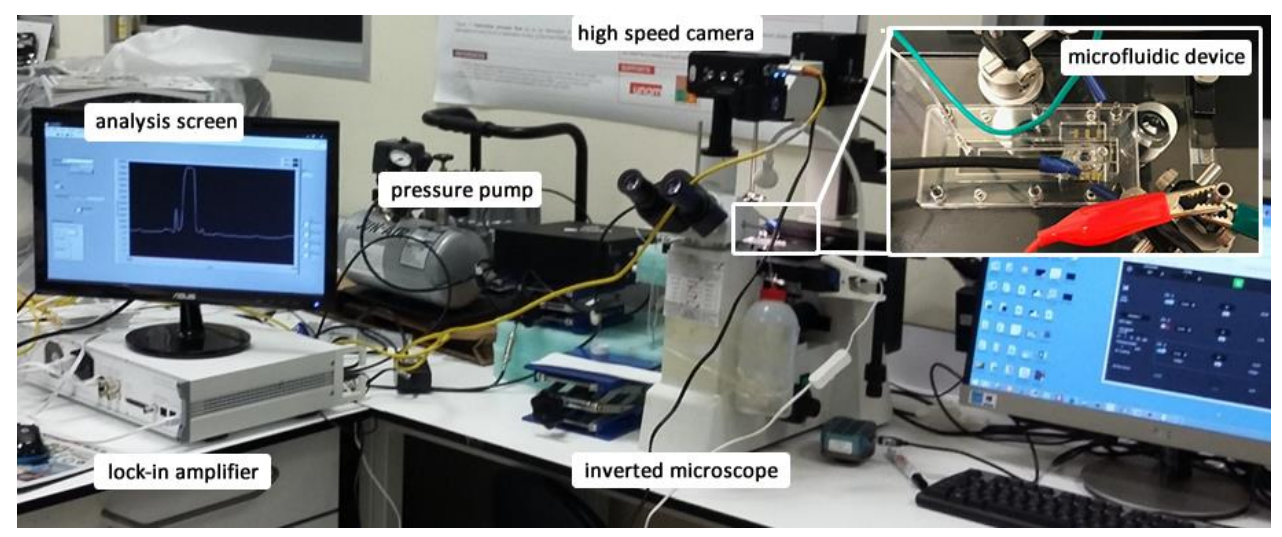

Figure. 1. The photography of the experimental setup developed for microfluidic cell differentiation. The upper right inset image shows an enlarged top-view of the microfluidic device with electrical connections. 


\subsection{Finite Element Analysis for Electrode Design}

A major step of the system design is determination of the channel dimensions (height, width, length) and the coplanar electrode dimensions (width and inter-electrode distance). In the literature although experimental approaches are common, numerical analysis tools provide a better insight and much shorter design cycle at this step. Hence, finite element analysis simulations (COMSOL 3.5) were performed to obtain the optimal channel and electrode dimensions. A snapshot of the 3D simulations is given in Figure 2. As seen, the particle under test was simulated as a spherical particle and the electric field generated by the coplanar electrodes are shown. As the particle is moved using a position sweep, the signal obtained from the measurement and the reference electrodes were obtained. The simulation was performed for varying channel and electrode dimensions. The results are given in section 3.2.

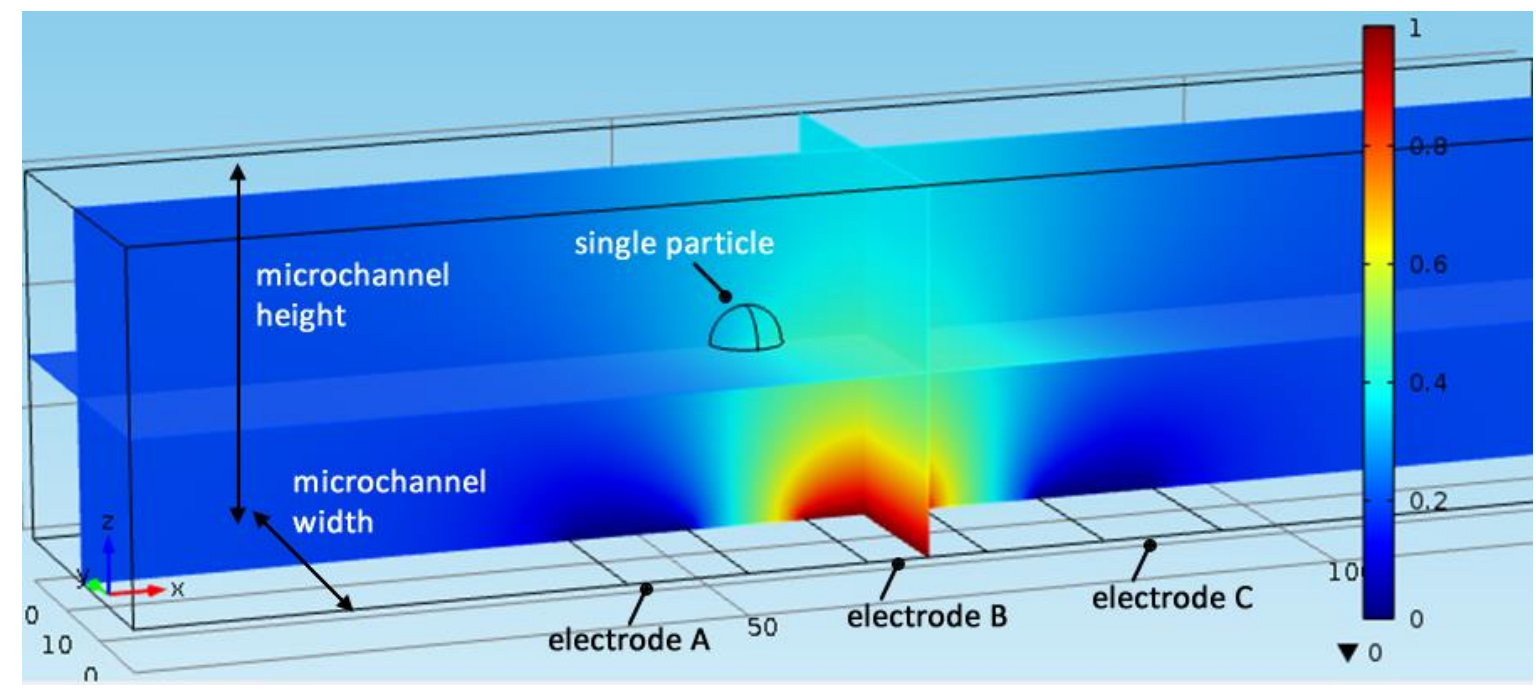

Figure. 2. An image of the 3D finite element analysis measurements used for channel and electrode geometry optimization.

\subsection{Solution Optimization for Rheological Performance}

Then, the working solution was optimized to obtain rapid particle focusing at the center of the microchannel. Several polymeric solutions were used for viscoelastic focusing (Yuan et al. 2018). In this study, polyethylene oxide (PEO) was used due its low cost and availability in multiple molecular weights. First, the viscosity of PEO solutions with varying molecular weights were determined using a rheometer (Anton Paar MCR301). For these measurements the polymer was dissolved in deionized water at a concentration of $0.1 \% \mathrm{w} / \mathrm{v}$. The results are given in Figure 3, where the measurement marks are the mean and the error bars represent 2 standard deviation of 5 repetitive measurements. Cone and plate (CP) measurement fixture (CP40-1) was used for the measurements. CP sample holder provides homogenous shear conditions due to constant shear rate with the conical gap. However hydrodynamic flow instabilities may also occur in CP fixtures as in the case for other fixtures (parallel plate, PP, and concentric cylinder, CC). For low viscosity fluids, secondary flow effects (centrifugal or inertial forces) may become dominant at high shear rates which disturbs the laminar flow conditions (Mezger 2014). In this study, the flow conditions were set so that the shear rate was kept between 100 and $1000 \mathrm{~s}-1$. As seen all four molecular weights provide almost constant viscosity, varying between 1 and $3 \mathrm{mPa} . \mathrm{s}$ as a function of polymer molecular weight. Hence in order to determine the polymer molecular weight, the focusing of particles were tested using red blood cell solutions. The $5 \mathrm{MDa}$ solution provided the best performance by focusing the suspended cells at the center of the channel at a distance of $2 \mathrm{~cm}$ from the inlet at an inlet gauge pressure of 200 mbar. These observations were performed using high speed camera imaging, which was only used for initial observation and verification steps and eliminated during the following impedance analysis results. 


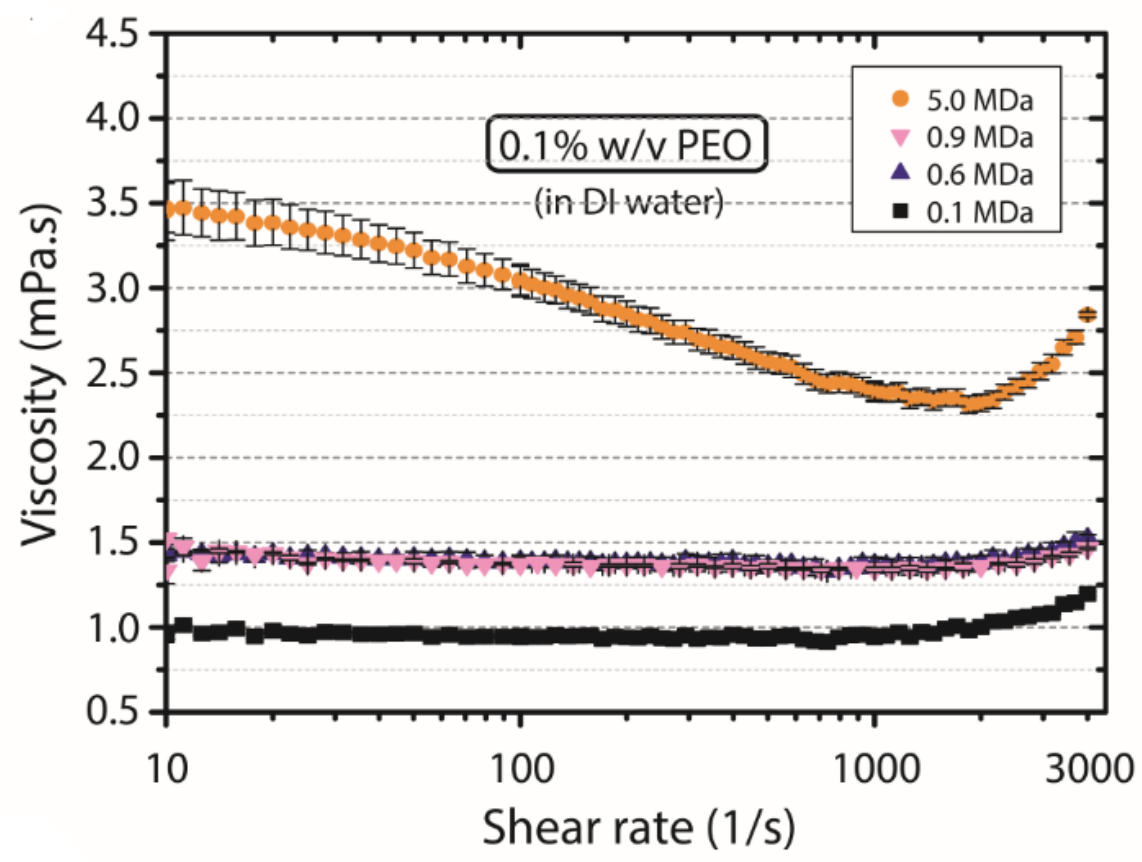

Figure. 3. Viscosity measurements of $0.1 \% \mathrm{w} / \mathrm{v}$ polyethylene oxide (PEO) solutions of various molecular weights in a wide range of shear rate.

\subsection{Solution Optimization for Cell Viability}

The final step in the solution optimization was obtaining the conductivity that yields the highest signal for the impedimetric detection. It is well-known that higher ionic conductivity of the medium leads to an improved signal for cellular detection application, since cells have a lipid containing membrane that behave as insulator (Serhatlioglu et al. 2019). However, increasing the solution ionic concentration may have adverse effects on cell integrity. The 5MDa PEO was dissolved $(0.1 \% \mathrm{w} / \mathrm{v})$ in three different ionic concentrations of PBS. Then, the cells were suspended in these solutions and were imaged under optical microscope. As seen in Figure 4, cells preserve their shape in 1X PBS solution. However when they are suspended in 3X PBS solution the number of viable cells decreased considerably. Additionally, survived cells have compromised membranes and appeared as starshaped which is an evidence of cell shrinkage. At 10X PBS most of the cells suffered lysis. Therefore, RBCs experiments cannot be performed with other PBS concentrations. A similar assay was performed for WBCs and it was concluded that for cell viability 1X PBS is the optimal solution.
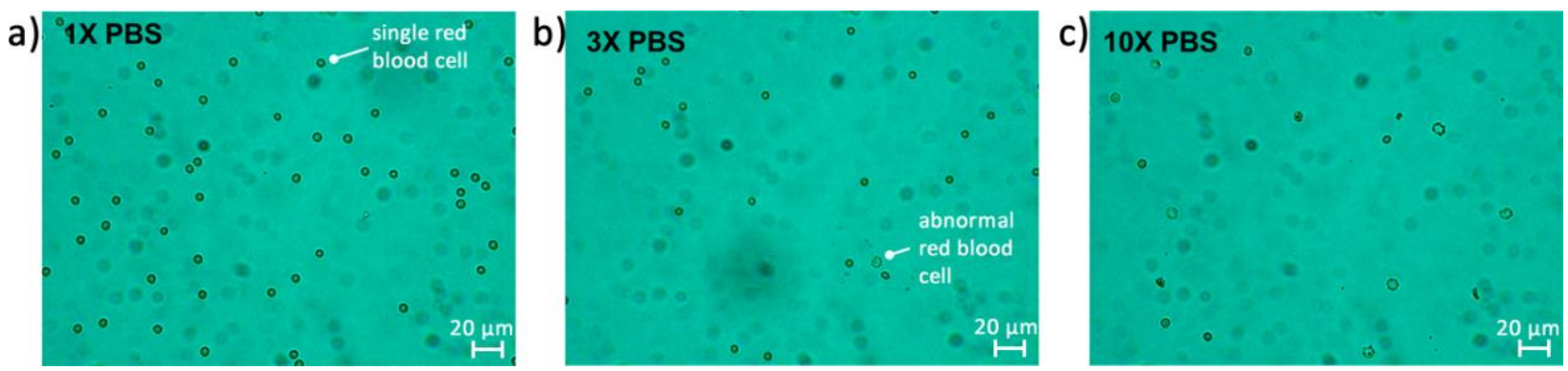

Figure. 4. Optical microscope images of red blood cells suspended in varying concentrations of PBS solutions: a) 1X, b) 3X, c) $10 \mathrm{X}$.

\section{Numerical and Experimental Results}

\subsection{Numerical Results}

The finite element modeling analysis explained in the previous section was used to determine the detection signal for a model spherical microparticle of $6 \mu \mathrm{m}$ in diameter with cell-like material properties. As seen from the schematic of the overall measurement system given in Figure 5, the system detects the particle based on the electrical signal change due to the presence of the particle in the detection zone over the microelectrodes. A lock-in amplifier system was used for these measurements since very low currents are detected. Any noise other than the measurement frequency should be rejected to obtain a satisfactory signal to noise ratio. 


\section{AC excitation signal}

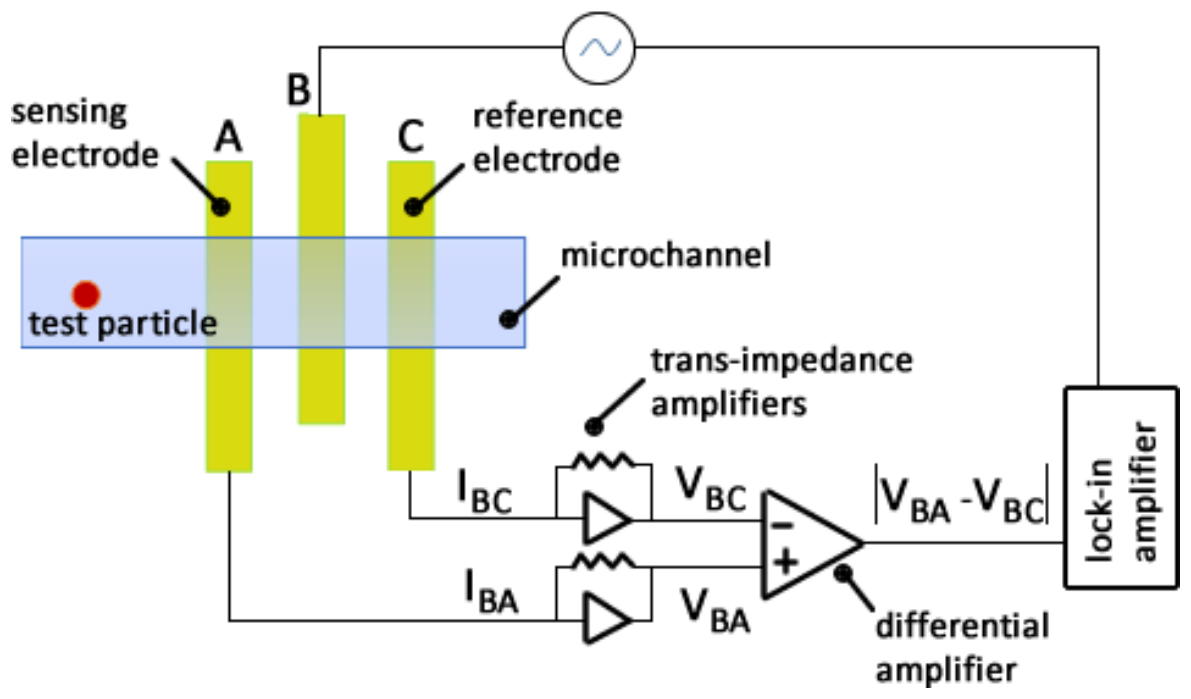

Figure. 5. A schematic of the impedance measurement system demonstarted the top-view of the detection zone together with the read-out electronics: TA:trans-impedanance amplifier, DA: differential voltage amplifier, LA: lock-in amplifier

The finite element model simulations were repeated for varying electrode and channel geometries and the signal measurement by the lock-in amplifier was calculated. Additionally, the measurement medium was also varied and the results for increasing ionic concentrations were obtained (given in Table 1) to demonstrate the importance of the PBS concentration. From these numerical results, the channel width and height were determined as $30 \mu \mathrm{m}$; and the electrode width and gap were set as $10 \mu \mathrm{m}$. Our results for these dimensions are given in Table 1. The detection signal that is given at the rightmost column (VBC-VBA) corresponds to the signal peak amplitude obtained when the particle is at the center-position between the first two electrodes (third column, IBC). The blank signal value (in the second column) was subtracted from this value to calculate the detection signal. Although the detection signal increases with increasing solution conductivity, the experiments were performed with $1 \mathrm{X}$ PBS not to compromise the cell integrity as explained in detail in section 2.4 .

Table 1. Simulation results for differential impedance measurements at varying ionic concentrations of PBS

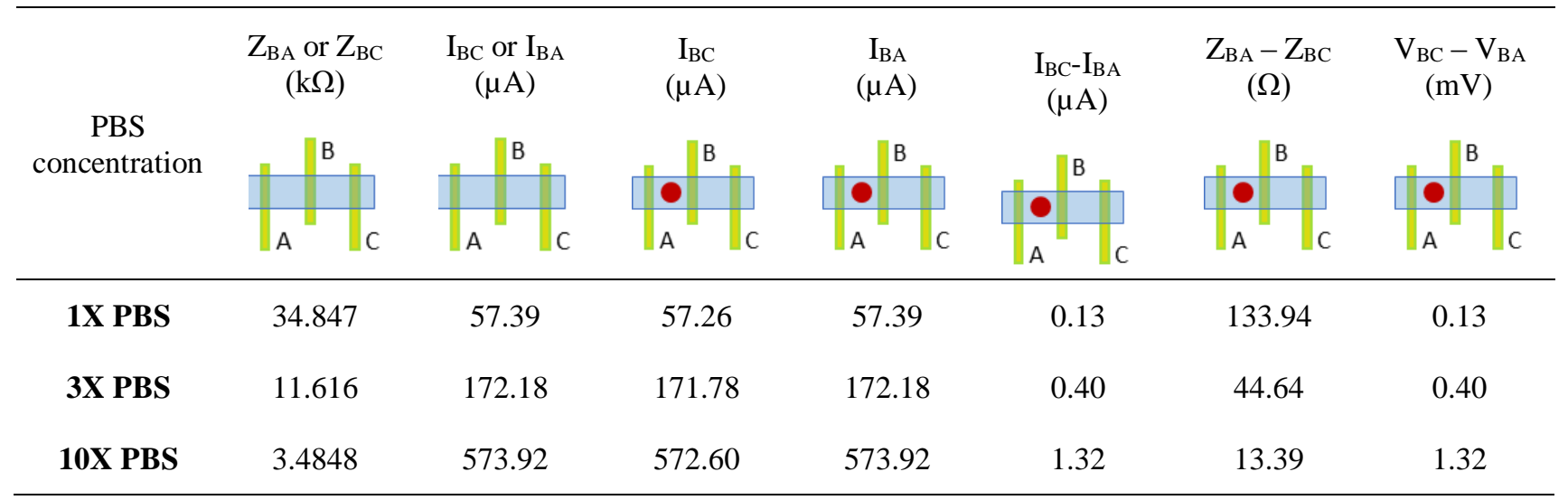

\subsection{Experimental Results}

After optimization of the channel, electrode geometry and the working liquid, the cell differentiation experiments were performed. The red blood cells (RBC) were obtained from a healthy voluntary donor. $20 \mu$ l of finger-prick blood was obtained and mixed with anticoagulant. Then the blood sample was centrifuged at $5000 \mathrm{rpm}$ for 3 min for RBC separation. $2 \mu 1$ of suspended RBCs were dispensed in $4 \mathrm{ml}$ of the viscoelastic solution optimized in the previous steps. The solution was used as fresh to prevent any bias due to cell deformation over time.

Since the number of white blood cells (WBCs) are significantly lower compared to RBCs, a cell line was used to test the performance of the system for WBCs by having much higher cell concentration. For that purpose mononuclear B lymphoblastic CCRF-SB leukaemia cell line (ATCC@ CCL-120TM) was acquired. The leukaemia cells (WBCs) were grown in cell culture flasks in a humidified environment (95\% air, 5\% CO2). The cells were grown in suspension cultures in RPMI complete medium (88\% RPMI 1640 medium, 10\% fetal bovine serum with \%1 Pen-Strep and \%1 glutamate) and sub-cultured every 3-4 days when they reach confluency. Confluent cells were centrifuged at $2500 \mathrm{~g}$ for $5 \mathrm{~min}$, then re-suspended in the viscoelastic PEO solution (5MDa, $500 \mathrm{ppm})$. The cells were diluted to a final density of 106 cells $/ \mathrm{ml}$. 
Finally the RBC and WBC cell suspension were pumped at three different pressure rates (150, 250, and 410 mbar) through the impedance-based viscoelastic cytometry device. A representative signal from a single experiment (RBC solution at $250 \mathrm{mbar}$ inlet pressure) is given in Figure 6a to demonstrate the electrical signals obtained from individual cells. As seen, each cell yields a positive and a negative peak due to the differential measurement. Individual signals corresponding to a single cell are given as close-up view. A characteristic signal can be derived from these measurements and signal amplitude and transit time can be defined for each cell as also shown in the Figure $6 \mathrm{~b}$. Each of these signals was analyzed to obtain the transit time, which is the time between the signal maxima and minima, as well as the signal amplitude maximum were obtained using a custom Matlab script. The results for two cell populations are given in Figure 7.

Leukemia cells are B lymphoblast white blood cell type and normally their size are larger than RBCs. Figure 7a demonstrates a clear difference in transit time for equal inlet pressures for signals between RBCs and WBCs. Mean values of transit time of WBCs are almost two times larger than RBCs. Additionally, the coefficient of variation (CV\%) values of WBCs are larger in comparison to $\mathrm{RBCs}$ due to the larger size variations in the WBC population, which was also verified by optical microscopy investigation. In Figure 7b, WBCs' signal amplitude mean values are almost three times larger than RBCs, however, WBC populations interlaced with RBC populations for each inlet pressure values. Also, WBC CV\% values of peak amplitudes are larger than that of RBCs, which is an evidence to the large size of WBCs. The measurements were obtained at a single measurement frequency of $2 \mathrm{MHz}$ and demonstrate that by analyzing the transit time and peak amplitude collectively it is possible to differentiate viscoelastically focused WBCs and RBCs impedimetrically.

These results are very promising in the sense that viscoelastic focusing is very successful in aligning the cells at the center of the channel so that a high-quality, i.e. low $\mathrm{CV} \%$, impedance detection was achieved for cell differentiation. Once the differentiation of thrombocytes is achieved, these results will pave the way for a whole blood analysis system that is based on microfluidic viscoelastic focusing and impedance detection.

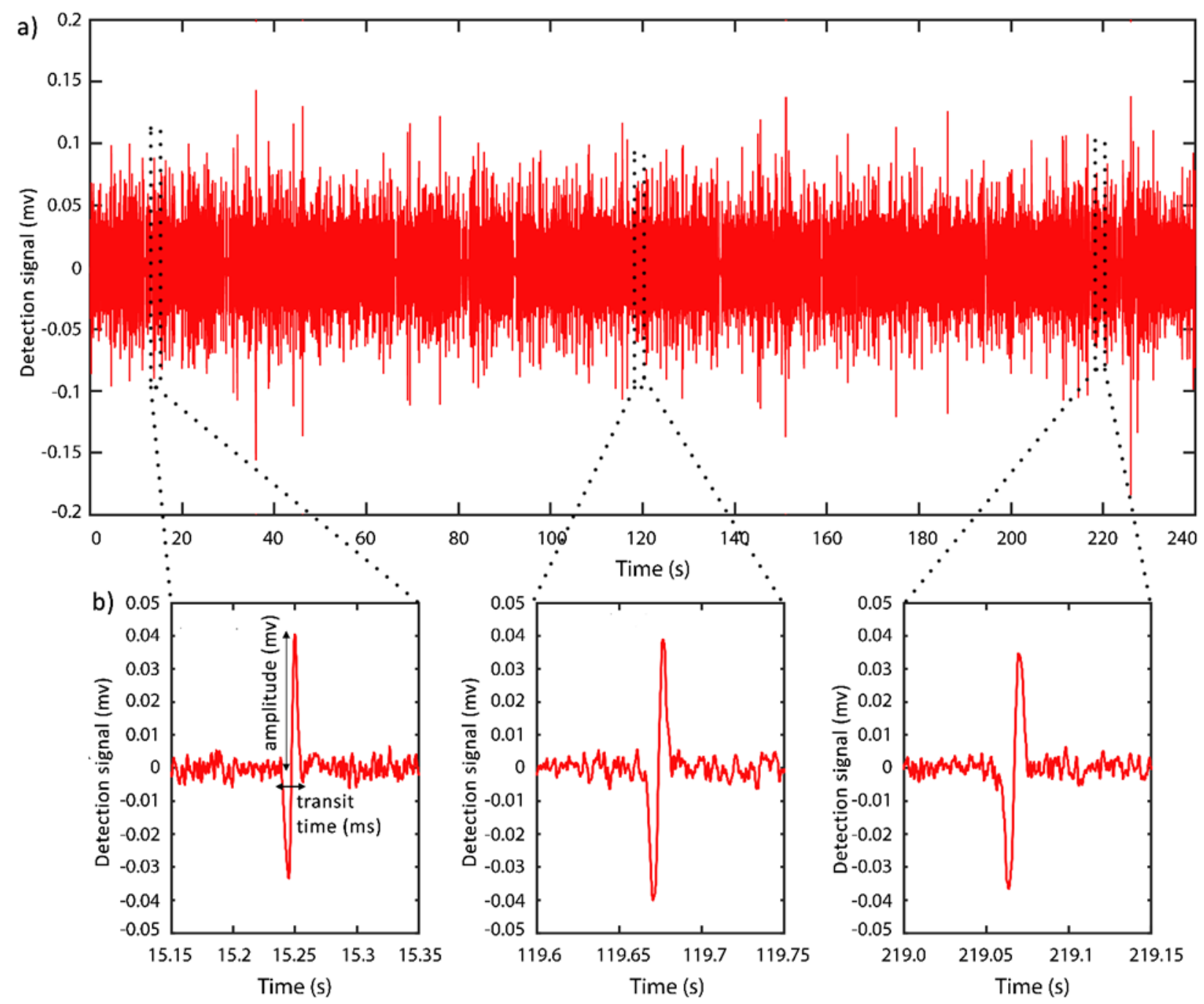

Figure. 6. (a)The lock-in amplifier signal output recorded for a portion of the experiments where the signals represent individual cells detected by the impedimetric measurement (inlet pressure of $250 \mathrm{mbar}$ ). (b) shows a close-up view of individual signals obtained from single cells with two characteristic peaks. The analysis parameters were defined on this characteristic signal as amplitude $(\mathrm{mV})$ and transit time $(\mathrm{ms})$ 
a)

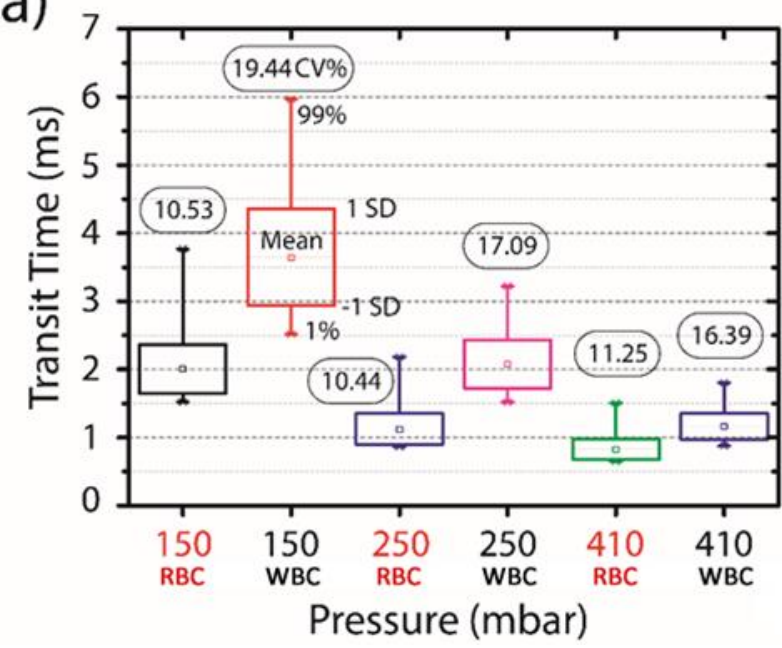

b)

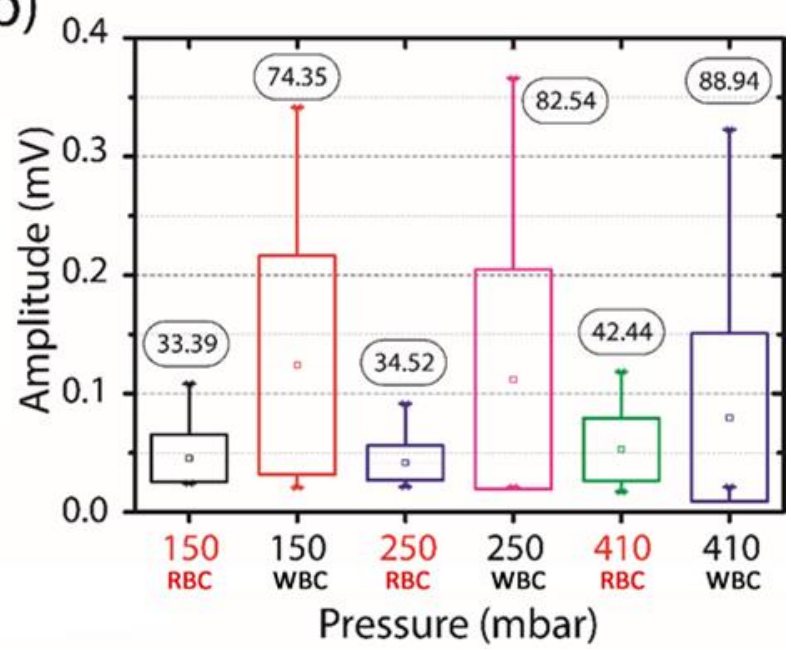

Figure. 1. The results of the impedance signal measurement analysis for RBC and WBC solutions analyzed at three different inlet pressures (150, 250 and 400 mbar); (a) transit time and (b) peak amplitude, for the comparison of RBC and WBC results. For each bar chart, the small square represents the mean value, the box represents the standard deviation, and the whisker lines represent the $99 \%$ and $1 \%$ population of the counted events. CV\% values are given on the top of each bar line.

\section{Conclusion}

The impedimetric identification of RBC and WBCs were achieved using a polyethylene oxide based viscoelastic focusing. It was shown that by careful design of the solution properties both the rheological and the electrical properties of the carrying solution can be tuned so that successful cell alignment and identification can be achieved. In case of the blood cells, the primary difference came from the transit time which is an indication of the cell size. When we run the system with 250 mbar of inlet pressure, a doubling of transit time was achieved which allows clear distinguishing of cell types. Although the two cell types that were analyzed have irregular cell shapes, their identification was possible by successfully aligning them at the sensing spot using viscoelastic solution. This study can pave the way towards a new generation of flow through cytometry and cell characterization systems that do not require additional design components or inlet flows for particle focusing.

\section{Acknowledgements}

The author acknowledges support from Dr. Kutay Icoz and Murat Serhatlioglu for biological experiments. The detection system was acquired by financial support (project no. 215E086) from the Scientific and Technological Research Council of Turkey (TUBITAK).

\section{Referanslar}

D’Avino, Gaetano, Francesco Greco, \& Pier Luca Maffettone. (2017). Particle Migration Due to Viscoelasticity of the Suspending Liquid and Its Relevance in Microfluidic Devices. Annual Review of Fluid Mechanics, 49(1), 341-60.

Daniele, Michael A., Darryl A. Boyd, David R. Mott, \& Frances S. Ligler. (2015). 3D Hydrodynamic Focusing Microfluidics for Emerging Sensing Technologies. Biosensors and Bioelectronics, 67, 25-34.

Dziubinski, M. (2012). Hydrodynamic Focusing in Microfluidic Devices. In Advances in Microfluidics. InTech.

Go, Taesik, Hyeokjun Byeon, \& Sang Joon Lee. (2017). Focusing and Alignment of Erythrocytes in a Viscoelastic Medium. Scientific Reports, 7. Nature Publishing Group: 41162.

Holmes, David, \& Hywel Morgan. (2010). Single Cell Impedance Cytometry for Identification and Counting of CD4 T-Cells in Human Blood Using Impedance Labels. Analytical Chemistry, 82(4), 1455-61.

Lu, Xinyu, Chao Liu, Guoqing Hu, \& Xiangchun Xuan. (2017). Particle Manipulations in Non-Newtonian Microfluidics: A Review. Journal of Colloid and Interface Science 500 (August). Academic Press: 182-201.

Mezger, T.G. 2014. The Rheology Handbook. Vincentz Network, 4th edition

Romeo, Giovanni, Gaetano D’Avino, Francesco Greco, Paolo A. Netti, \& Pier Luca Maffettone. (2013). Viscoelastic FlowFocusing in Microchannels: Scaling Properties of the Particle Radial Distributions. Lab on a Chip, 13(14), 2802. 
Schauer, Thadeus. (1995). Symmetrical and Asymmetrical Flow Field-Flow Fractionation for Particle Size Determination. Particle \& Particle Systems Characterization, 12(6), 284-88.

Serhatlioglu, Murat, Mohammad Asghari, Mustafa Tahsin Guler, \& Caglar Elbuken. (2019). Impedance-Based Viscoelastic Flow Cytometry. Electrophoresis, 40(6), 906-913.

Wahlund, Karl-Gustav. (2013). Flow Field-Flow Fractionation: Critical Overview. Journal of Chromatography A, $1287,97-112$.

Yamada, Masumi, \& Minoru Seki. (2006). Microfluidic Particle Sorter Employing Flow Splitting and Recombining. Anal. Chem, 78(4), 1357-62.

Yi, Changqing, Qi Zhang, Cheuk-Wing Li, Jun Yang, Jianlong Zhao, \& Mengsu Yang. (2006). Optical and Electrochemical Detection Techniques for Cell-Based Microfluidic Systems. Analytical and Bioanalytical Chemistry, 384(6), $1259-68$.

Yuan, Dan, Qianbin Zhao, Sheng Yan, Shi-Yang Tang, Gursel Alici, Jun Zhang, \& Weihua Li. (2018). Recent Progress of Particle Migration in Viscoelastic Fluids. Lab on a Chip, 18, 551. 